\title{
Analisis Kebutuhan Pendampingan dan Kompetensi Pendamping Pelaku Usaha Industri Jamu
}

Penulis Ninuk Purnaningsih ${ }^{*}$, Titi Mawasti, Yudhistira Saraswati

Afiliasi
Departemen Sains Komunikasi dan Pengembangan Masyarakat, Fakultas Ekologi Manusia, Institut Pertanian Bogor, Dramaga Bogor 16680, Indonesia

\section{Kata Kunci \\ P Pendamping \\ $\rightarrow$ CPOTB \\ $\rightarrow \mathrm{SNI}$}

$\begin{array}{ll}\text { Diterima } & 9 \text { April } 2017 \\ \text { Direvisi } & 6 \text { Mei } 2017 \\ \text { Disetujui } & \text { 21 Juli } 2017\end{array}$

*Penulis korespondensi Ninuk Purnaningsih

Departemen Sains Komunikasi dan Pengembangan

Masyarakat, Fakultas Ekologi Manusia, Institut Pertanian Bogor, Dramaga Bogor 16680 Email :

npurnaningsih@gmail.com

\section{ABSTRAK}

Kabupaten Sukoharjo, Provinsi Jawa Tengah adalah pusat industri pengolahan dan pemasar jamu di Indonesia. Terdapat sekitar 60 pengusaha dan pedagang jamu (dari skala kecil, menengah, hingga besar) yang tergabung dalam Koperasi Jamu Indonesia (KOJAI). Pada tahun 2012, Kecamatan Nguter diresmikan sebagai "Kampung Jamu". Dalam perkembangannya, industri jamu Nguter mengalami permasalahan diantarannya sulitnya mendapatkan izin edar dari Badan POM karena produk belum memenuhi standar Good Manufacturing Practices (GMP). Kemampuan para pelaku usaha, sulitnya mendapatkan bahan baku yang berkualitas dan penerapan teknologi yang sederhana menjadi penyebab utama sulitnya menghasilkan produk terstandar. Berdasarkan hal tersebut dan dalam rangka menghadapi globalisasi perdagangan, maka diperlukan pendampingan kepada pelaku usaha industri jamu. Kompetensi pendamping sangat penting perannya dalam mendampingi para pengusaha industri jamu. Kompetensi yang diperlukan pendamping antara lain pengetahuan mengenai Cara Pembuatan Obat Tradisional yang Baik (CPOTB) dan Standar Nasional Indonesia (SNI). Metode yang digunakan dalam penelitian ini adalah metode kaji tindak, yang menggabungkan antara metode survey dengan aksi pemberdayaan di masyarakat. Kegiatan dalam penelitian ini meliputi studi literatur/ dokumentasi, survey, wawancara mendalam, focus group discussion (FGD), dan workshop

\section{PENDAHULUAN}

Adalah hak konsumen (masyarakat) untuk mendapatkan produk yang bermutu baik dari obat tradisional dan makanan yang memenuhi persyaratan keamanan, kegunaan dan persyaratan mutu lainnya. Produk obat tradisional termasuk jamu hasil UMKM yang diklaim mempunyai manfaat kesehatan atau khasiat khusus namun belum memiliki ijin edar telah dijual secara luas di pasaran dan dipercaya begitu saja oleh konsumen, terutama bagi konsumen yang belum memahami tentang ijin produk. ljin edar obat tradisional dan makanan merupakan hal yang sangat penting dalam proses

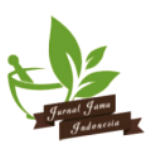


penjualan produk karena pada dasarnya setiap produk, baik produk pangan, kosmetika maupun obat-obatan membutuhkan ijin edar sebelum dilempar ke pasaran, namun pelaku usaha industri jamu seringkali mengeluhkan rumitnya proses mendapatkan ijin edar bagi produk jamunya.

Tulisan ini merupakan sebagian dari hasil penelitian yang berjudul Strategi Penguatan Kapasitas Pelaku Usaha Industri dan Pemasar Jamu di Kabupaten Sukoharjo Jawa Tengah, yang bertujuan: (1) menganalisis kebutuhan pendampingan bagi pelaku usaha industri jamu, khususnya industri mikro - kecil, (2) menganalisis peran pendamping dan kompetensi pendamping dalam pengajuan ijin edar obat tradisional terutama produk jamu.

Beberapa konsep penting berkaitan dengan obat tradisional dan industri obat tradisional adalah sebagai berikut:

(1) Obat Tradisional adalah bahan atau ramuan bahan yang berupa bahan tumbuhan, bahan hewan, bahan mineral, sediaan galenik atau campuran dan bahan-bahan tersebut, yang secara traditional telah digunakan untuk pengobatan berdasarkan pengalaman.

(2) Industri Obat Tradisional adalah industri yang memproduksi obat traditional dengan total asset diatas Rp 600.000.000,- (enam ratus juta rupiah), tidak termasuk harga tanah dan bangunan.

(3) Industri Kecil Obat Tradisional adalah industri obat tradisional dengan total asset tidak lebih dari Rp. 600.000.000,- (enam ratus juta rupiah), tidak termasuk harga tanah dan bangunan

(4) Usaha Jamu Racikan adalah usaha peracikan, pencampuran, dan atau pengolahan obat tradisional dalam bentuk rajangan, serbuk, cairan, pilis, tapel atau parem dengan skala kecil, dijual di satu tempat tanpa penandaan dan atau merk dagang.

(5) Usaha Jamu Gendong adalah usaha peracikan, pencampuran pengolahan dan Pengedaran obat tradisional dalam bentuk cairan, pitis, tapel atau parem, tanpa penandaan dan atau merk dagang serta dijajakan untuk langsung digunakan.

(6) Memproduksi adalah membuat, mencampur, mengolah, mengubah bentuk mengisi, membungkus dan atau memberi penandaan obat tradisional untuk diedarkan.

(7) Mengedarkan adalah menyajikan, menyerahkan, memiliki atau menguasai persediaan di tempat penjualan dalam Industri Obat Tradisional atau di tempat lain termasuk di kendaraan dengan tujuan untuk dijual kecuali jika persediaan di tempat tersebut patut diduga untuk dipergunakan sendiri.

(8) Usaha Industri Obat Tradisional harus mempekerjakan secara tetap sekurang-kurangnya seorang Apoteker warganegara Indonesia sebagai penanggung jawab teknis.

(9) Industri Obat Tradisional dan Industri Kecil Obat Tradisional wajib mengikuti Pedoman Cara Pembuatan Obat Tradisional yang Baik (CPOTB). ([Kemenkes] Kementrian Kesehatan. 1990)

Izin Edar adalah bentuk persetujuan registrasi bagi produk obat, obat tradisional, kosmetik, suplemen makanan, dan makanan yang dikeluarkan oleh Badan Pengawas Obat dan Makanan Republik Indonesia agar produk tersebut secara sah dapat diedarkan di wilayah Indonesia (BPOM 2009)

\section{METODE}

Penelitian ini dilakukan di Kabupaten Sukoharjo, di sentra industri jamu di wilayah Kecamatan Nguter Metode yang digunakan dalam penelitian ini adalah metode kaji tindak, yang menggabungkan antara metode survey dengan aksi pemberdayaan di masyarakat. Kegiatan dalam penelitian ini meliputi studi literatur/dokumentasi, survey terhadap 25 pelaku usaha pemasar jamu dan 10 pelaku usaha industri, wawancara mendalam, dan diskusi kelompok terarah (focus group discussion /FGD). Pelaku usaha jamu yang menjadi fokus penelitian ini adalah industri jamu skala mikro dan kecil, serta pemasar jamu di Pasar Nguter, dan pedagang jamu gendong.

\section{HASIL DAN PEMBAHASAN}

\section{Gambaran Lokasi Kecamatan Nguter Kabupaten Sukoharjo}

Kecamatan Nguter merupakan salah satu kecamatan yang ada di Kabupaten Sukoharjo, Provinsi Jawa Tengah. Posisi Kecamatan Nguter cukup strategis karena jarak antara ibukota kecamatan dengan ibukota kabupaten hanya $\pm 8.2 \mathrm{Km}$ dengan akses jalan yang sudah baik, selain itu kecamatan ini berbatasan langsung dengan dua kabupaten lain yaitu Kabupaten Karanganyar dan Kabupaten Wonogiri. Akses menuju Kecamatan Nguter relatif mudah. Dari Kota Surakarta (Solo) menuju Kabupaten Sukoharjo lalu ke Kecamatan Nguter dapat ditempuh dengan menggunakan

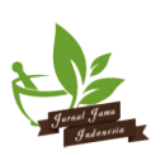


angkutan umum seperti bis atau angkutan umum dengan tarif relatif murah.

Penduduk Kecamatan Nguter mempunyai mata pencaharian yang beragam. Mata pencaharian pada sektor pertanian semakin lama semakin ditinggalkan karena lahan pertanian semakin menyempit. Akibatnya banyak penduduk khususnya usia muda yang memilih untuk mencari pendapatan dari sektor non pertanian seperti menjadi pekerja pabrik atau merintis usaha. Penduduknya banyak yang merantau ke kota - kota besar di Indonesia. Jumlah penduduk yang merantau semakin banyak terutama kaum muda.

Mata pencaharian khas masyarakat Kecamatan Nguter adalah berdagang jamu gendong. Penjual jamu gendong asal Sukoharjo terdapat di kota - kota besar Jabodetabek, Semarang, Bandung dan kota lain di Indonesia. Banyak industri rumah tangga yang memproduksi jamu dengan menggunakan teknologi yang masih sederhana. Akibatnya industri jamu semakin lama semakin berkembang yang juga diikuti dengan berkembangnya proses produksi dan teknologi yang digunakan.

\section{Gambaran Usaha Jamu di Kabupaten Sukoharjo}

Pada tahun 1965 Kabupaten Sukoharjo khususnya Kecamatan Nguter mulai dikenal dengan Kampung Jamu. Selain dari banyaknya industri besar dan kecil menengah, hal yang menjadi identik Kampung Jamu Nguter adalah banyaknya penduduk yang bekerja sebagai pedagang jamu gendong di beberapa kota besar di Indonesia. Pedagang jamu gendong di setiap desa mencapai sekitar 100 pedagang.

Di Kecamatan Nguter terdapat Koperasi Jamu Indonesia (KOJAI). Koperasi ini merupakan organisasi yang beranggotakan pelaku usaha jamu baik pemasar maupun pengolah di wilayah Kabupaten Sukoharjo dan sekitarnya. KOJAI dirintis pada tahun 1977 dimana pada saat itu masih bergabung dalam wadah Gabungan Perusahaan Jamu Indonesia (GPJI). Pada tahun 1989 di Jakarta, diadakan seminar dan pekan Jamu seluruh Indoensia, serta serah terima jabatan dari Bapak Drs.Moertedjo kepada Ibu BRA Moeryati Sudibyo, dengan perubahan nama GPJI menjadi GP (Gabungan Pengusaha) Jamu dan Obat Tradisional.

Pada tanggal 30 Juli 1995, KOJAI resmi berbadan hukum dengan nama organisasi Koperasi Jamu Indonesia (KOJAI) yang diketuai oleh Ny.Suwarsi Moertedjo dengan anggota 30 pengrajin jamu. Hingga sekarang jumlah anggota yang bergabung dengan KOJAI mencapai 75 anggota yang terdiri dari pengolah dan pemasar jamu. Kegiatan utama KOJAl adalah menghimpun para pelaku usaha jamu, melakukan pembimbingan, serta pengarahan bagaimana membuat jamu yang sehat, aman, dan baik.

Pada Tahun 2012, Nguter diresmikan sebagai "Kampung Jamu". Pengembangan industri di Kecamatan Nguter sejalan dengan tujuan dari pengembangan wilayah Kabupaten Sukoharjo dimana salah satunya adalah terwujudnya tata ruang wilayah yang sesuai peruntukannya dan dapat memberikan kontribusi terhadap pengembangan Provinsi Jawa Tengah dan wilayah sekitarnya melalui pengembangan sektor pertanian, industri, pariwisata, dan perdagangan. Kawasan industri jamu Nguter diharapkan mampu mendorong kemajuan produksi jamu pada umumnya. Kawasan industri jamu ini terdiri dari industri usaha jamu, pemasar, dan pasar jamu Nguter. Dampak lain yang diharapkan adalah meningkatnya pertumbuhan ekonomi di Kabupaten Sukoharjo.

Jumlah industri jamu dan kosmetik menurut data dari Dinas Perdagangan dan Perindustrian Kabupaten Sukoharjo Tahun 2013 sebanyak 29 industri yang tersebar di beberapa wilayah kecamatan. Jumlah industri tersebut merupakan industri yang mendaftar merek dagang ke Dinas Perdagangan dan Perindustrian Kabupaten Sukoharjo (Tabel 1) . Produk yang dihasilkan dari industri jamu di Kabupaten Sukoharjo adalah jamu olahan yang berbentuk serbuk, sirup, dan kapsul yang dijual di toko atau warung, sedangkan pedagang jamu gendong menjual jamu berupa minuman jamu yang dijual berkeliling. Jamu yang diproduksi berasal dari bahan-bahan alami yang sebagian besar diproses secara tradisonal.

\section{Karakteristik Pelaku Usaha Jamu}

Pelaku usaha adalah setiap orang perseorangan atau kelompok yang menyelenggarakan kegiatan usaha dalam berbagai bidang ekonomi. Pelaku usaha jamu dapat diidentifikasi melalui supply chain produk jamu yang akan dijelaskan terperinci pada sub-bab selanjutnya. Secara garis besar, pelaku usaha jamu dibagi menjadi industri dan pemasar.

Gambar 1 menyajikan karakteristik pelaku usaha jamu di Kabupaten Sukoharjo. Industri/pengolah adalah individu atau kelompok yang memproduksi jamu, sedangkan pemasar adalah yang menjual produk hasil dari pengolah kepada konsumen. Industri terbagi menjadi industri pengolah jamu yang secara lokal

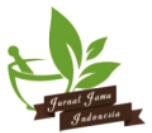


Tabel 1 Perbandingan Jenis Aset Produksi Industri Jamu di Kabupaten Sukoharjo Tahun 2015

\begin{tabular}{|c|c|c|c|}
\hline No & Aset Produksi & Industri Skala Menengah - Besar & Industri Rumahtangga (mikro - kecil) \\
\hline 1 & Gudang & $\begin{array}{l}\text { Penyimpanan untuk bahan mentah } \\
\text { maupun produk yang sudah jadi. } \\
\text { Gudang terpisah dengan standar } \\
\text { penyimpan yang telah disesuaikan. }\end{array}$ & $\begin{array}{l}\text { Penyimpanan untuk produk tempat } \\
\text { penyimpanan bahan baku biasanya } \\
\text { hanya ditempatkan di dapur atau di } \\
\text { depan rumah. }\end{array}$ \\
\hline 2 & Mobil angkutan & $\begin{array}{l}\text { Mobil angkutan terdiri dari bebrapa } \\
\text { jenis, yaitu mobil untuk mengambil } \\
\text { bahan, pendistribusian produk, dan } \\
\text { kegiatan operasional lain. }\end{array}$ & $\begin{array}{l}\text { Rata - rata mobil angkutan } 1-2 \text { baik } \\
\text { milik pribadi maupun sewa. Mobil } \\
\text { dipergunakan untuk mengangkut bahan } \\
\text { dan barang. }\end{array}$ \\
\hline 3 & Tempat produksi & Ada pabrik khusus untuk produksi. & $\begin{array}{l}\text { Tempat produksi dilakukan di rumah } \\
\text { dan tempat khusus di sekitar rumah. }\end{array}$ \\
\hline 4 & Timbangan & $\begin{array}{l}\text { Timbangan besar dan timbangan } \\
\text { untuk pengemasan produk. }\end{array}$ & $\begin{array}{l}\text { Timbangan besar dan timbangan untuk } \\
\text { pengemasan yang lebih sederhana }\end{array}$ \\
\hline 5 & Mesin penggiling & $\begin{array}{l}\text { Ada beberapa mesin penggiling bahan } \\
\text { baku }\end{array}$ & $\begin{array}{l}\text { Banyak yang belum mempunyai mesin } \\
\text { penggiling, penggilingan dilakukan di } \\
\text { tempat penggilingan bahan. }\end{array}$ \\
\hline 6 & Alat pengepres & Ada alat pengepresan & $\begin{array}{l}\text { Banyak yang belum mempunyai alat } \\
\text { pengepresan }\end{array}$ \\
\hline 7 & $\begin{array}{l}\text { Alat pengukur kadar } \\
\text { air }\end{array}$ & Ada alat pengukur kadar air & Tidak memiliki alat pengukur kadar air \\
\hline 8 & Alat sortir/ terpal & $\begin{array}{l}\text { Ada alat sortir/ terpal beragam } \\
\text { ukuran }\end{array}$ & Alat sortir/ terpal masih terbatas \\
\hline 9 & Alat sortir/ tampah & $\begin{array}{l}\text { Wadah "tampah "setiap bahan baku } \\
\text { sudah dipisah }\end{array}$ & $\begin{array}{l}\text { Cenderung satu wadah "tampah" untuk } \\
\text { banyak jenis bahan baku }\end{array}$ \\
\hline 10 & Alat ekstrasi & Ada alat ekstrasi untuk membuat pil & Belum ada alat ekstrasi \\
\hline 11 & Laboratorium & Sudah ada laboratorium dan laboran & Belum mempunyai laboratorium khusus \\
\hline
\end{tabular}

Sumber: Data Primer 2015

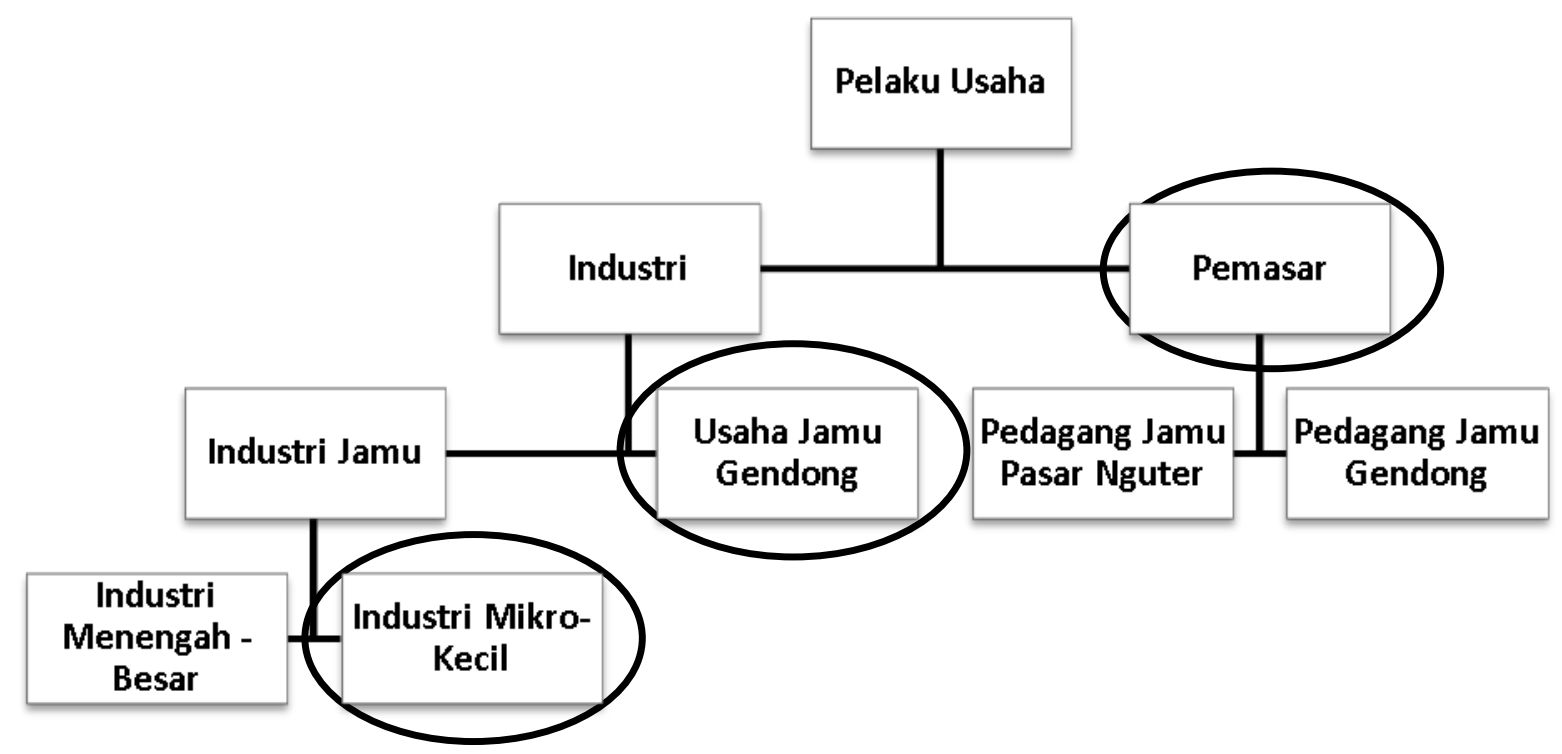

Gambar 1 Pelaku Usaha Jamu di Kabupaten Sukoharjo 
disebut pengrajin jamu dan usaha jamu gendong. Industri jamu diklasifikasikan menjadi industri jamu skala menengah - besar dan industri mikro - kecil. Pemasar terdiri dari pedagang jamu di Pasar Nguter dan pedagang jamu gendong. Jadi usaha jamu gendong, merupakan unit pengolah/industri sekaligus pemasar jamu.

\section{Industri Jamu}

Dalam penelitian ini, Industri jamu di Kabupaten Sukoharjo diklasifikasikan menjadi industri skala menengah-besar dan industri mikro-kecil (selanjutnya disebut industri skala rumahtangga). Responden berjumlah 10 industri jamu yang terdiri dari 3 industri jamu skala menengah - besar dan 7 industri jamu skala rumahtangga. Pembahasan pada sub-bab berikut adalah perbandingan industri jamu skala menengahbesar dan industri jamu skala rumahtangga secara umum.

Kategori industri skala menengah - besar dicirikan mempunyai tenaga kerja relatif banyak, pekerja sesuai dengan bidang keahlian, menggunakan mesin yang otomatis, dan produk yang dihasilkan banyak jenisnya. Industri jamu skala rumahtangga mempunyai ciri-ciri yaitu tenaga kerja yang terlibat mayoritas adalah keluarga dan relatif sedikit, pekerja mengerjakan semua pekerjaan, menggunakan manual, atau mesin sederhana, dan produk yang dihasilkan terbatas.

Lama usaha pengolahan jamu beragam. Usaha industri jamu tertua adalah sejak tahun 1987 sedangkan termuda berdiri tahun 2007. Pada indusri skala menengah - besar usaha yang dirintis relatif belum lama jika dibandingkan dengan industri rumahtangga. Industri skala rumahtangga umumnya adalah usaha turun temurun keluarga.

Dalam merintis usaha diperlukan sebuah modal usaha. Modal usaha para industri jamu berasal dari berbagai sumber. Pada industri skala besar modal berasal dari bantuan lembaga keuangan, sedangkan industri skala rumahtangga pola pembiayaan masih mengandalkan modal sendiri. Berikut sumber modal yang diperoleh pengrajin jamu:

\section{a. Modal Sendiri}

Modal pribadi berasal dari dana yang dikumpulkan dari pekerjaan terdahulu. Modal pribadi pada awal usaha sekitar $30 \%$ - 100\%. Industri jamu yang masih berskala mikro - kecil modal sendiri mencapai $100 \%$, modal yang diperlukan sekitar Rp 5.000.000,00. Untuk industri yang sejak awal dipersiapkan sebagai industri skala menengah - besar, modal mengandalkan dari bantuan bank atau mitra.

b. Pinjaman Bank

Pinjaman modal mempunyai dua jenis yaitu pinjaman yang diberikan dari bank secara langsung diberikan di saat usaha mulai berjalan dan pengajuan peminjaman kepada bank oleh pelaku usaha industri. Bank memberikan bantuan pinjaman langsung tanpa pengajuan untuk menunjang selama proses porduksi. Kisaran bantuan pinjaman langsung antara $\mathrm{Rp}$ 1.000.000,00 - Rp 5.000.000,00.

c. Bantuan Pemerintah

Bantuan pemerintah yang diterima berasal dari Dinas Perindustrian dan Perdagangan Kabupaten Sukoharjo. Bantuan diberikan berupa alat-alat produksi.

d. Bantuan Mitra

Bantuan juga didapat dari mitra yang berasal dari beberapa instansi pemerintahan maupun swasta. Mitra memberikan bantuan berupa modal finansial (bantuan uang), modal bahan baku dan modal alat-alat produksi.

Aset produksi yang digunakan untuk industri jamu terdiri dari beberapa alat. Uraian kepemilikan sarana dan prasarana dikelompokkan pada industri besar dan industri rumahtangga seperti disajikan pada Tabel 1.

Dalam proses pengolahan jamu diperlukan bahan baku. Bahan baku yang diperlukan dalam produkssi jamu di Nguter diperoleh dari beberapa sumber yaitu:

a. Pemasok dari Luar Wilayah Kabupaten Sukoharjo

Pemasok bahan baku umumnya dari luar Kecamatan Nguter dan Kabupaten Sukoharjo. Mereka berasal dari wilayah sentra komoditas kunyit, jahe, temulawak, dan bahan baku jamu lainnya seperti di Wonogiri, Karanganyar, Boyolali, Semarang, dan Lampung. Bahan baku yang dikirim dengan memesan terlebih dahulu. Pemasok dari luar daerah tersebut merupakan pedagang pengumpul yang membeli dari para petani.

b. Pasar Nguter dan Sekitarnya

Pasar Nguter selain menjual produk jamu jadi juga menyediakan bahan baku untuk pembuatan jamu. Selain di Pasar Nguter bahan baku juga diperoleh dari toko-toko jamu di wilayah Kota Solo. Ada satu pengrajin jamu yang bermitra dengan salah satu toko yang ada di salah satu pasar tradisional di Solo.

\section{c. Produksi sendiri}

Bahan baku untuk jamu seperti kunyit, temulawak, kencur, dan jahe diperoleh dengan budidaya sendiri. Budidaya dilakukan di sekitar rumah, seperti di halaman atau pekarangan rumah. Namun panen yang

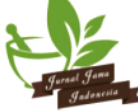


dihasilkan dari budidaya tersebut tidak dapat memenuhi kebutuhan produksi, karena jenis tanaman yang dapat dibudidayakan terbatas. Beberapa bahan baku seperti kayu manis, cengkeh, dan kapulaga yang harus dibeli.

Tenaga kerja yang ada dalam usaha pengolahan jamu dapat dikelompokkan ke dalam kriteria sebagai berikut:

\section{a. Tenaga kerja terampil}

Tenaga kerja terampil merupakan tenaga kerja yang bekerja sesuai dengan bidang keahlian yang dimilikinya. Dalam usaha ini tenaga kerja terampil yang dipekerjakan hanya di beberapa pabrik yang skala usaha besar. Tenaga kerja direkrut dengan seleksi dengan kriteria tertentu dan hanya sedikit yang berdasarkan hubungan kekerabatan. Pada tenaga kerja terampil ini biasanya juga memiliki pendidikan tinggi hingga bergelar master. Penempatan kerja tenaga kerja terampil sesusai dengan bidang keahlian yang dimiikinya.

\section{b. Tenaga kerja tak terampil}

Tenaga kerja tak terampil merupakan tenaga kerja yang bekerja tidak sesuai dengan bidang keahlian yang dimiliki atau tidak memiliki bidang keahlian tertentu. Tenaga kerja ini dengan kriteria ini banyak ditemukan dalam usaha ini. Umumnya mereka mempunyai hubungan kekerabatan dengan pemilik usaha seperti saudara atau tetangga. Proses seleksi masuk hanya berdasarkan kepercayaan. Tenaga kerja ini ditempatkan sesuai dengan kondisi yang diperlukan. Keahlian akan dimiliki oleh tenaga kerja dengan sendirinya.

Sedangkan untuk jumlah pekerja terlihat perbedaan pada industri skala besar dan industri rumahtangga. Industri skala besar mempekerjakan tenaga kerja dalam jumlah besar. Jumlah tenaga kerja yang bekerja dikelompokkan sebagai berikut:

\section{a. 1-5 Pekerja}

Jumlah pekerja pada industri jamu skala mikro. Pekerja biasanya adalah anggota rumah tangga atau yang masih mempunyai hubungan kekerabatan. Pekerja sifatnya tetap dan pekerja musiman. Pekerja musiman dipekerjakan saat ada pemesanan besar atau saat - saat permintaan maksimal.

\section{b. $10-50$ Pekerja}

Jumlah pekerja pada pengrajin skala kecil. Pekerja berasal dari anggota rumah tangga dan pekerja dari dalam maupun luar daerah.

c. Lebih dari 50 Pekerja
Salah satu pengrajin jamu yang dikelompokkan ke dalam usaha skala menengah mempekerjakan sekitar 210 karyawan di berbagai bagian produksi. Pekerja berasal dari wilayah Sukoharjo dan kota lain di Indonesia. Pekerja ini sifatnya adalah karyawan tetap yang diupah sesuai dengan kontrak kerja.

Sistem upah pekerja dalam industri pengrajin jamu dapat dikelompokkan sebagai:

a. Upah Borongan

Sistem upah borongan diberikan kepada pekerja musiman. Pekerja musiman hanya ada di saat - saat tertentu. Pekerja ini berasal dari lingkungan sekitar. Upah dibayar saat mereka bekerja dengan hitungan perhari atau per siklus produksi.

b. Upah Rutin

Pekerja tetap biasanya diupah rutin per minggu atau per bulan. Besarnya upah disesuaikan dengan pekerjaan. Upah perminggu berkisar antar Rp $150.00,00$ hingga Rp 210.000,00.

\section{Analisis Kebutuhan Pendampingan bagi Pelaku Usaha Industri Jamu: Masalah-masalah dalam Proses Pengajuan Ijin Edar}

Bagian ini disarikan dari hasil penelitian Purnaningsih (2015). Proses pengajuan ijin edar merupakan proses yang tidak mudah dan dapat dipahami oleh semua orang, terutama produsen yang belum pernah melakukan pengurusan ijin edar sebelumnya. Bagi pelaku usaha dengan skala usaha yang kecil dan menengah, masih terdapat kekhawatiran dan kurangnya kepercayaan diri dalam hal persiapan untuk melakukan persiapan ijin edar. Kekhawatiran tersebut bukan berarti tidak adanya keinginan atau karena penggunaan bahan baku yang berbahaya, melainkan karena tidak siap untuk memenuhi standar CPOTB yang dirasa cukup rumit.

Hasil penelitian terdahulu di Pasar Jamu Nguter, Sukoharjo, terdapat banyak sekali (ratusan) produk jamu yang dihasilkan oleh "pengrajin" atau pengusaha jamu tradisional di Kecamatan Nguter berpotensi untuk dipasarkan, namun belum memiliki ijin edar dari Badan Pengawasan Obat dan Makanan (BPOM). Dari sekitar 60 pelaku usaha jamu yang tergabung dalam KOJAI di kecamatan Nguter, hanya terdapat 10 pelaku usaha yang telah mendaftarkan diri ke BPOM sebagai produsen jamu (Tabel 2). Dari 10 pelaku usaha yang terdaftar ini adalah pelaku usaha industri mikro sampai industri jamu yang cukup besar, di mana baru sebagian dari produknya yang didaftarkan ke BPOM sebagai 
Tabel 2 Pelaku Usaha Jamu Terdaftar BPOM di Kecamatan Nguter Kabupaten Sukoharjo Tahun 2016

\begin{tabular}{|c|c|c|c|}
\hline No & Nama Sarana & Alamat & $\begin{array}{l}\text { Jumlah Produk yang } \\
\text { Didaftarkan }\end{array}$ \\
\hline 1 & CV WISNU JKW & $\begin{array}{l}\text { Dk. Nguter RT } 01 \text { RW 05, Ds. Nguter, Kec. } \\
\text { Nguter, Kab. Sukoharjo } \\
\text { Telp: 0271-593858 }\end{array}$ & 26 \\
\hline 2 & PT SABDO PALON & $\begin{array}{l}\text { Gatakrejo No. } 9 \text { RT } 01 \text { RW 01, Nguter } \\
\text { Telp dan Fax: 0271-593793 }\end{array}$ & 155 \\
\hline 3 & UD GATUTKACA & $\begin{array}{l}\text { Jalan Kepodang No. } 17 \text { Joho, Sukoharjo } \\
\text { Telp: 0271-593286 }\end{array}$ & 12 \\
\hline 4 & $\begin{array}{l}\text { PT GUJATI LIMAPULUH } \\
\text { SEMBILAN UTAMA }\end{array}$ & $\begin{array}{l}\text { Jl. Raya Solo-Wonogiri, Dk. Guntur RT } 01 \\
\text { RW 02, Ds. Gupit, Kec. Nguter } \\
\text { Telp: 0271-6594659/6594164, } \\
\text { Fax: 0271-6594305 }\end{array}$ & 82 \\
\hline 5 & PJ PUNTODEWO & Nguter RT 02 RW 5, Sukoharjo & 6 \\
\hline 6 & PJ CAPING GUNUNG & Nguter RT 01 RW 04, Sukoharjo & 1 \\
\hline 7 & UD PJ BISMA SEHAT & $\begin{array}{l}\text { Nguter RT } 01 \text { RW 07, Sukoharjo } \\
\text { Telp: 0271-6594012,Fax: 0271-6594023 }\end{array}$ & 71 \\
\hline 8 & PJ MONGGO MAS & Nguter RT 03 RW 05, Sukoharjo & 1 \\
\hline 9 & PJ ANOMAN & Nguter RT 02 RW 06, Sukoharjo & 26 \\
\hline 10 & PJ NARODO & Nguter RT 03 RW 05, Sukoharjo & 9 \\
\hline
\end{tabular}

produk yang berijin edar BPOM. Misalnya untuk produk dari PJ ANM yang masih berskala kecil, memiliki sebanyak 41 produk jamu, sedangkan yang terdaftar di BPOM baru 26 produk, artinya hampir separuh dari produk PJ ANM belum berizin edar BPOM. Contoh lain adalah PT SPL yang merupakan pelaku usaha skala besar telah mendaftarkan semua produknya dengan total 115 produk (BPOM 2016b dan Purnaningsih 2015)

Para pelaku usaha skala kecil dan menengah yang menjadi responden menyebutkan masih banyak masalah yang dihadapi, misalnya produk yang masih bermasalah secara formulasi (belum ditemukan formulasi yang terbaik dari segi tampilan atau proses pengolahan), kurangnya sumberdaya, peralatan penunjang, dan juga masalah lain seperti sanitasi dan pengolahan limbah yang belum terstruktur hingga bangunan yang konstruksinya belum sesuai syarat CPOTB. Permasalahan yang dihadapi oleh para pelaku usaha jamu ini pada dasarnya juga dipengaruhi oleh kurangnya tenaga ahli yang mampu mengatasi masalah-masalah yang dihadapi, atau memberikan arahan menuju perbaikan CPOTB.

Koperasi Jamu Indonesia (KOJAI) telah berusaha untuk melakukan pendampingan, namun masih terbatas pada masalah-masalah registrasi secara umum saja dan tidak mencakup masalah-masalah te knis pengolahan atau masalah-masalah spesifik dari setiap pelaku usaha. Karena pada dasarnya setiap pelaku usaha memiliki masalah-masalah yang berbeda-beda, antara lain: (1) masalah pada proses pengeringan bahan baku, (2) masalah pada pengolahan produk, dan (3) masalah pada pengemasannya.

Pelaku usaha umumnya telah mempunyai apoteker di mana ini menjadi syarat bagi sebuah industri pengolahan obat. Apoteker berperan dalam memformulasikan dan mengontrol bahan baku atau khasiat jamu, namun personalia yang dibutuhkan untuk menerapkan standar CPOTB tidak cukup hanya seorang apoteker. Berkaitan dengan pencapaian ijin edar, masalah-masalah yang berkaitan dengan sanitasi, limbah, ataupun teknis pengolahan merupakan aspek yang sangat penting dan memerlukan ranah ilmu dan pemahaman yang tidak dimiliki oleh seorang apoteker. Pendampingan bagi produsen yang akan mengurus ijin edar ini sangat diperlukan, guna membantu persiapan produknya, dan mengatasi masalah-masalah yang berkaitan dengan hal-hal teknis yang tidak tercakup oleh tugas seorang apoteker, serta proses pengajuan ijin edarnya. 


\section{Analisis Kompetensi Pendamping untuk Proses Pengajuan Ijin Edar}

Berikut adalah kompetensi yang sebaiknya dimiliki oleh seorang pendamping bagi produsen obat tradisional termasuk jamu untuk proses pengajuan ijin edar. Kompetensi tersebut meliputi kompetensi dalam: (a) Proses persiapan produk yang dihasilkan, (b) Proses persiapan pendaftaran ijin edar produk, (c) Proses sosial dalam melakukan pendampingan terhadap para pelaku usaha industri jamu.

\section{A. Proses Persiapan Produk yang Dihasilkan}

1. Mampu menganalisis proses pengolahan produk sesuai Standar SNI.

Seorang pendamping harus memiliki pengetahuan dan juga kemampuan untuk memahami produk yang dihasilkan oleh industri yang didampingi. Hal ini terkait dengan kategori produk di dalam Standar Nasional Indonesia (SNI) yang dikeluarkan oleh Badan Standarisasi Nasional (BSN). Pendamping juga harus memahami benar bagaimana proses atau cara pengolahan produk hingga produk sampai di tangan konsumen. Hal ini termasuk aspek pengemasan produk, misalnya bahan pengemas yang sesuai untuk produk, bahan pengemas yang aman dan tidak bereaksi dengan produk, tanpa meninggalkan masalah efisiensi biaya dari proses produksi. Atau singkatnya, pendamping harus memahami diagram alir proses pengolahan produk secara utuh dan mengoreksinya jika terdapat hal yang kurang tepat.

Misalnya untuk produk dengan kategori sirup, maka pendamping harus memahami bagaimana produk yang dibuat dapat disebut sebagai sirup, dan masuk kategori sirup yang dipersyaratkan oleh BSN. Produk tersebut harus mengandung gula sebanyak $35 \mathrm{~g} / 100 \mathrm{~g}$ dalam bentuk gula sakarosa (BSN, 2013). Maka pendamping sebaiknya memahami, bagaimana syarat dari SNI ini dapat terpenuhi. Pendamping harus paham bagaimana jumlah gula sakarosa dalam produk sirup tersebut dapat mencapai $35 \%$, bagaimana perkiraan formulasi produk, bagaimana proses pengolahan produk sehingga dapat diperoleh kandungan gula yang sesuai, dan juga bagaimana proses pengemasan (bahan pengemas) dan handling yang sesuai agar kadar gula dalam produk dapat dipertahankan selama proses distribusi hingga sampai di tangan konsumen. Pada akhirnya, masalah ini akan berkaitan dengan formulasi dan diagram alir yang diperlukan untuk pendaftaran ijin edar yang merupakan salah satu syarat administrasi.

\section{Mampu memecahkan masalah yang ditemui dalam proses pengolahan produk}

Dalam kegiatan pendampingan, hal yang cukup penting adalah membantu pihak yang kita dampingi untuk memecahkan masalah yang dihadapi. Pendamping dituntut untuk memahami bagaimana pengolahan yang baik dari produk, dan juga cara mengatasi masalah yang mungkin muncul dari proses pengolahan tersebut. Karena hal ini mencakup hal-hal yang sifatnya teknis dan berkaitan dengan berbagai proses yang sifatnya saintis yang mungkin tidak atau belum dipahami oleh produsen karena berbagai hal.

Misalnya, untuk produk jahe instan, produk diolah menggunakan gula dalam jumlah yang cukup banyak dan juga pemanasan. Masalah yang mungkin timbul dari proses pemanasan gula ini adalah pencoklatan non enzimatis atau karamelisasi, di mana produk yang dihasilkan menjadi berwarna coklat sehingga tidak menarik lagi. Seorang pendamping harus paham, bagaimana suhu yang tepat dan pengaturan api untuk proses pemanasan sehingga tidak terjadi pemanasan yang berlebihan, bagaimana proses pengadukan harus dilakukan, waktu yang tepat untuk penambahan gula, dsb.

\section{Kreatif dalam mengatasi keterbatasan sumberdaya}

Masalah keterbatasan sumberdaya merupakan masalah yang cukup sering dijumpai dalam sebuah industri rumah tangga atau industri yang baru memulai produksi. Seorang pendamping akan dituntut untuk dapat mengembangkan kreativitas guna menyiasati keterbatasan sumberdaya ini.

Misalnya, untuk proses pencetakan permen, jika industri yang kita dampingi belum memiliki mesin ekstruder atau pemotong yang dapat menghasilkan produk dengan ukuran yang sesuai, maka dapat disiasati dengan menggunakan pemotong sejenis penggaris seperti yang biasa digunakan oleh pekerja pabrik tahu, sehingga meskipun tanpa ekstruder dapat dihasilkan produk dengan ukuran yang sesuai.

Masalah lain misalnya adalah keterbatasan alat berupa oven otomatis untuk proses pengeringan atau masalah cuaca yang tidak menentu, maka pendamping dapat menyarankan untuk mencoba membuat oven sederhana dengan memanfaatkan LPG dan rak, sedangkan pengaturan suhunya dapat diatasi dengan memasang termometer saja.

\section{Memahami standar CPOTB}

Seorang pendamping harus memahami benar bagaimana standar Cara Pembuatan Obat Tradisional

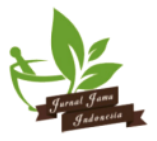


yang Baik (CPOTB). CPOTB harus dipenuhi karena CPOTB merupakan hal yang paling mendasar dalam proses persiapan produk guna pengajuan ijin edar produk. CPOTB yang harus diterapkan oleh produsen tidak hanya dilihat dari segi proses pengolahannya, namun juga hal-hal lain yang terkait. Pendamping harus memahami bagaimana produsen harus membuat administrasi yang teratur dan terarah, misalnya dalam bentuk log book harian dan log book produksi, kegiatan produksi yang mencakup bahan baku hingga pengolahan, pengemasan, pengawasan, sanitasi, dokumentasi, verifikasi, inspeksi, hingga pada produk kembalian atau penarikan produk dan manajemen keluhan. Selain itu pendamping juga harus memahami bagaimana peran dan kualifikasi personalia yang sesuai dalam pengolahan produk, baik dari segi organisasi, kualifikasi dan juga tanggung jawab, serta pelatihan bagi semua personil yang terlibat. Bangunan dan peralatan juga merupakan faktor penting yang harus diperhatikan dalam proses pendampingan. Hal yang harus diperhatikan ialah masalah lokasi bangunan, higiene dan sanitasi, serta rancang bangun pabrik dan ruangan, atau pemasangan dan penempatan peralatan. Tabel 3 menyajikan prinsip umum CPOTB dan Kompentensi yang dibutuhkan oleh pedamping.

Pada Tabel 3 tersebut diidentifikasi kompetensi yang diperlukan bagi seorang pendamping tentang prinsip umum CPOTB, meliputi: pedoman umum, personalia, bangunan, peralatan, sanitasi dan hygiene. Kompetensi tersebut secara lengkap dapat dilihat pada Tabel 4 dan 5.

Tabel 3 Prinsip umum CPOTB dan kompetensi yang dibutuhkan pendamping

\begin{tabular}{llcl} 
No Kategori СРОТВ & Standar СРОТВ & $\begin{array}{c}\text { Kompetensi yang Dibutuhkan } \\
\text { Pendamping }\end{array}$ \\
\hline
\end{tabular}

1 Pedoman Umum Pedoman tentang obat tradisional, bahan Pengetahuan untuk memahami awal, bahan baku, simplisia, bahan masing-masing pedoman, baik secara pengemas, produk antara, produk ruahan, definisi yang mudah dijelaskan produk jadi, pembuatan, produksi, maupun implementasi di lapangan. pengolahan, pengemasan, pengawasan, Kemampuan menerapkan pedoman pengawasan mutu, sanitasi, dokumentasi, umum dalam proses produksi. verifikasi, inspeksi diri, bets, lot, kalibrasi, karantina, nomor bets atau nomor lot, produk kembalian, penarikan kembali, dan keluhan

\begin{tabular}{|c|c|c|}
\hline Personalia & $\begin{array}{l}\text { 1. Personalia hendaknya mempunyai } \\
\text { pengetahuan, pengalaman, keterampilan, } \\
\text { dan kemampuan yang sesuai dengan } \\
\text { tugas dan fungsinya, jumlah yang cukup, } \\
\text { serta sehat sehingga mampu } \\
\text { menjalankan tugas dan kewajiban yang } \\
\text { dibebankan. } \\
\text { 2. Organisasi, kualifikasi dan tanggung } \\
\text { jawab yang terstruktur } \\
\text { 3. Pelatihan yang terjadwal, rutin dan } \\
\text { terdokumentasi }\end{array}$ & $\begin{array}{l}\text { 1. Memunyai kemampuan untuk } \\
\text { menjelaskan bagaimana cara dan } \\
\text { strategi untuk merekrut personalia } \\
\text { dengan kemampuan yang baik dan } \\
\text { sesuai dengan kebutuhan industri. } \\
\text { 2. Menjelaskan pentingnya organisasi } \\
\text { yang terstruktur dan pembagian } \\
\text { tugas yang jelas serta terkualifikasi } \\
\text { dari segi personil di dalam industri. } \\
\text { 3. Memberikan pengertian tentang } \\
\text { pentingnya pelatihan yang } \\
\text { terjadwal dan berkelanjutan serta } \\
\text { dokumentasi pelatihan sehingga } \\
\text { dapat dilacak pengaruh atau } \\
\text { perubahan yang terjadi sebelum } \\
\text { dan sesudah pelatihan. }\end{array}$ \\
\hline
\end{tabular}


Tabel 3 Prinsip umum CPOTB dan kompetensi yang dibutuhkan pendamping (lanjutan)

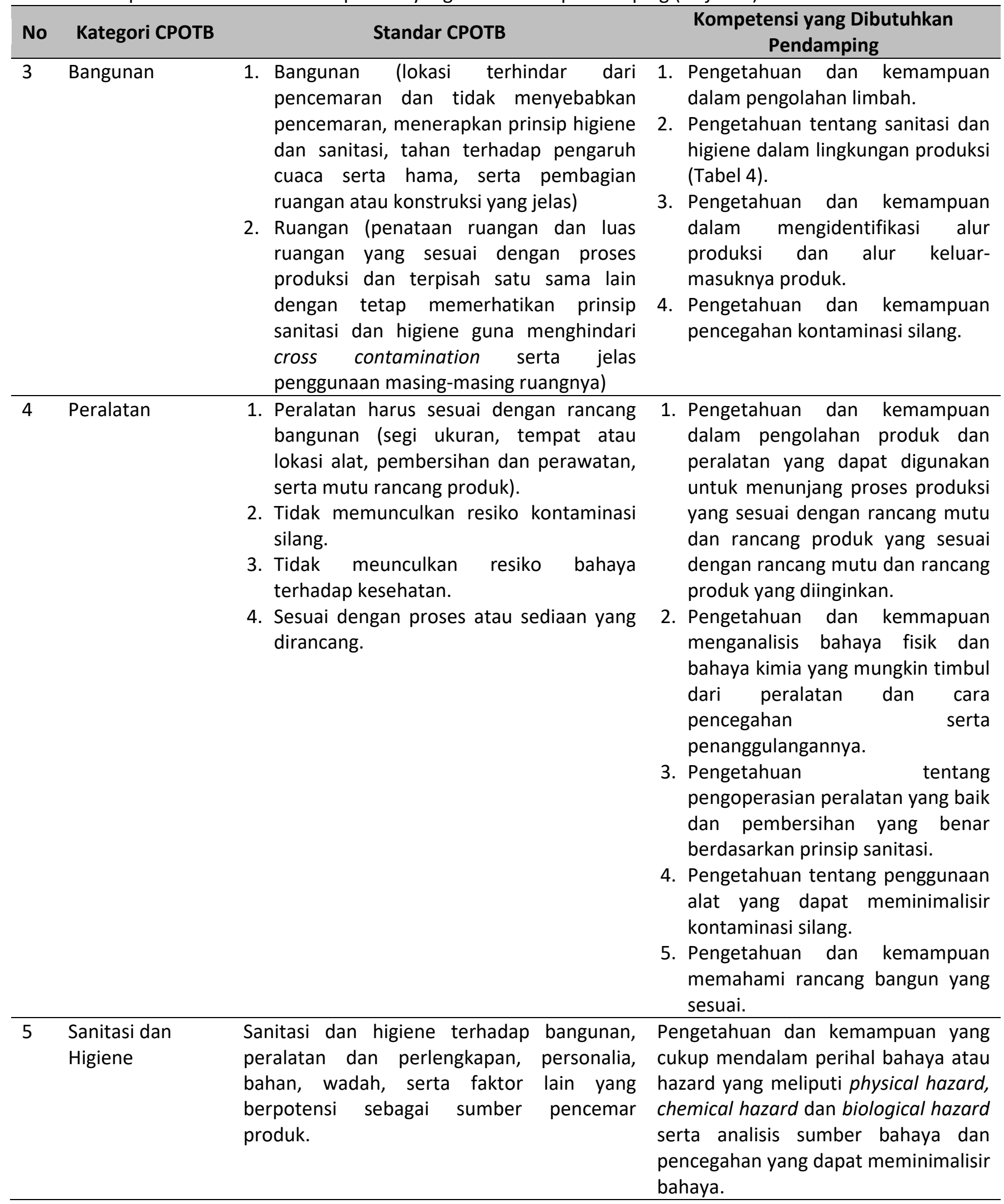


Tabel 4 Prinsip sanitasi dan higiene dalam CPOTB dan kompetensi yang dibutuhkan pendamping

\begin{tabular}{ccc}
\hline No & $\begin{array}{c}\text { Kategori } \\
\text { Sanitasi dan } \\
\text { Higiene }\end{array}$ & Prinsip Dasar \\
\hline 1 & Personalia & $\begin{array}{l}\text { 1. } \\
\text { Karyawan yang diterima masuk telah menjalani } \\
\text { berbagai tes kesehatan dan juga dilakukan tes } \\
\text { kesehatan secara berkala. }\end{array}$
\end{tabular}

2. Penerapan higiene perorangan dengan baik, dilakukan dengan pelatihan secara berkala.

3. Karyawan yang mengidap suatu penyakit atau mengalami luka terbuka yang berpotensi menurunkan kualitas produk dilarang untuk menangani produk maupun terlibat dalam proses produksi sampai sembuh kembali.

4. Karyawan wajib mencuci tangan dan memerhatikan kebersihan diri setiap akan memasuki ruangan produksi, dan perlu dipasang peringatan untuk penerapan budaya cuci tangan dan higiene perorangan.

5. Karyawan selalu melaporkan setiap keadaan pabrik, peralatan, atau personalia yang menurut penilaian mereka dapat menurukan kualitas produk. Hal ini perlu dilakukan sebuah pelatihan dan penanaman pemahaman bagi setiap personil untuk selalu memerhatikan lingkungan kerja dan ikut serta dalam setiap proses penjaminan mutu produk.

6. Karyawan menghindari kontak langsung antara anggota badan dengan bahan baku, produk antara dan produk ruahan (hal ini dapat diterapkan misalnya dengan menggunakan sarung tangan).

7. Karyawan menggunakan pakaian kerja, penutup rambut, masker, sarung tanag, dsb yang bersih sesuai dengan tugasnya, serta disediakan tempat ganti pakaian sehingga tidak terjadi kontaminasi dari pakaian yang digunakan di luar ruangan produksi.

\begin{aligned} \hline 2 Bangunan 1. & Tersedianya jamban, tempat cuci tangan yang \\ & dilengkapi dengan sabun dan alat pengering \\ & yang baik, dalam jumlah dan kapasitas serta \\ & kualitas yang memadai. \\ 2. & Tersedianya ruangan berupa dapur atau ruang \\ & makan yang khusus disediakan untuk tempat \\ & menyimpan atau mengonsumsi makanan \\ & sehingga tidak ada makanan yang masuk ke \\ & ruang prosuksi yang sesuai dengan syarta \\ & kebersihan. \end{aligned}

Kompetensi yang Dibutuhkan Pendamping

Pengetahuan dan kemampuan menganalisa bahaya yang dapat muncul atau cemaran yang bersumber dari pekerja baik yang berupa fisik (misalnya rambut, kuku, bulu mata), kimia (misal pekerja yang sedang menggunakan obat untuk luka luar dan mengandung bahan kimia non-pangan), serta bahaya mikrobiologi (Staphylococcus sp. atau $E$. coli dari tangan pekerja)

Pengetahuan dan kemampuan tentang sanitasi dan higiene tempat produksi.

Misal : Kadar chlorine yang dibutuhkan untuk pembersihan ruangan atau alat harus sesuai, sabun cuci tanagn yang sesuai (liat kandungan bahan kimia dalam sabun), atau penggunaan pestisida yang sesuai untuk menangani 
Tabel 4 Prinsip sanitasi dan higiene dalam CPOTB dan kompetensi yang dibutuhkan pendamping (Ianjutan)

\begin{tabular}{|c|c|c|c|}
\hline No & $\begin{array}{c}\text { Kategori } \\
\text { Sanitasi dan } \\
\text { Higiene }\end{array}$ & Prinsip Dasar & $\begin{array}{l}\text { Kompetensi yang Dibutuhkan } \\
\text { Pendamping }\end{array}$ \\
\hline & & $\begin{array}{l}\text { 3. Penggunaan rotentisida dan pestisida yang } \\
\text { sesuai dan tidak mengontaminasi peralatan, } \\
\text { bahan baku, bahan pengemas, produk antara, } \\
\text { produk ruahan, dan produk jadi. } \\
\text { 4. Ruangan dibersihkan dengan prosedur yang } \\
\text { sesuai sebelum dan sesudah produksi. }\end{array}$ & masalah yang timbul. \\
\hline 3 & Peralatan & $\begin{array}{l}\text { 1. Sanitasi dengan prosedur dan bahan pembersih } \\
\text { yang sesuai. } \\
\text { 2. Peralatan yang akan dipakai harus dipastikan } \\
\text { dahulu kebersihannya. } \\
\text { 3. Peralatan setelah dipakai dibersihkan (bagian } \\
\text { luar dan dalam) sesuai dengan prosedur sanitasi } \\
\text { dan prosedur pembersihan alat, disimpan dan } \\
\text { dijaga pada kondisi yang bersih dan sesuai } \\
\text { prosedur. } \\
\text { 4. Peralatan yang dapat dipindahkan sebaiknya } \\
\text { dilakukan pembersihan pada ruangan yang } \\
\text { terpisah dari ruangan pengolahan untuk } \\
\text { menghindari kontaminasi bahan pembersih. }\end{array}$ & $\begin{array}{l}\text { Pengetahuan dan kemampuan } \\
\text { analisa terhadap material } \\
\text { peralatan dan reaksi kimia yang } \\
\text { mungkin terjadi anatara peralatan } \\
\text { dengan bahan pembersih serta } \\
\text { kemampuan dan pengetahuan } \\
\text { untuk memahami prosedur } \\
\text { pembersihan alat. } \\
\text { Misal : Alat yang terbuat dari } \\
\text { logam, maka harus dicari bahan } \\
\text { pembersih dengan kandungan } \\
\text { yang tidak bereaksi dengan logam } \\
\text { dari peralatan. }\end{array}$ \\
\hline
\end{tabular}

Tabel 5 CPOTB proses pra poduksi, produksi dan pasca produksi serta kompetensi yang dibutuhkan pendamping

\begin{tabular}{|c|c|c|c|}
\hline No & $\begin{array}{c}\text { Kategori CPOTB } \\
\text { Pengolahan/Pasca } \\
\text { Produksi }\end{array}$ & Prinsip Dasar & $\begin{array}{c}\text { Kompetensi yang Dibutuhkan } \\
\text { Pendamping }\end{array}$ \\
\hline 1 & $\begin{array}{l}\text { Penyiapan bahan } \\
\text { baku }\end{array}$ & $\begin{array}{l}\text { 1. Pemeriksaan organoleptik dan laboratoris } \\
\text { bahan baku yang masuk maupun yang } \\
\text { akan digunakan. } \\
\text { 2. Pemberian label yang mencakup informasi } \\
\text { nama bahan baku berikut nama latinnya, } \\
\text { nama supplier, nama daerah dan juga } \\
\text { tanggal penerimaan bahan baku. Hal ini } \\
\text { untuk mempermudah pengontrolan bahan } \\
\text { baku dan identifikasi bahan baku. } \\
\text { 3. Pencatatan setiap pemasukan, pengeluran } \\
\text { serta jumlah yang tersisa dari bahan baku } \\
\text { yang meliputi nama, tanggal penerimaan } \\
\text { atau pemakaian, nama dan alamat } \\
\text { pemasok atau supplier. } \\
\text { 4. Sortasi simplisia yang akan digunakan } \\
\text { untuk membersihkan dan membebaskan } \\
\text { simplisia dari bahan asing, kotoran } \\
\text { maupun bahan pencemar yang lain. } \\
\text { 5. Pencucian dengan cara atau prosedur yang }\end{array}$ & $\begin{array}{l}\text { 1. Pengetahuan dan kemampuan } \\
\text { dalam memahami cross } \\
\text { contamination bahan baku. } \\
\text { 2. Pengetahuan dan kemampuan } \\
\text { menganalisa bahan baku yang } \\
\text { digunakan, serta spesifikasi } \\
\text { bahan baku yang baik dan } \\
\text { memenuhi syarat. } \\
\text { 3. Pengetahuan dan kemampuan } \\
\text { menyusun standar bahan baku } \\
\text { yang sesaui dengan kebutuhan } \\
\text { industri. } \\
\text { 4. Kemampuan organoleptik (bau, } \\
\text { warna, rasa) bahan baku. } \\
\text { 5. Pengetahuan tentang prosedur } \\
\text { pembersihan yang tepat untuk } \\
\text { bahan baku dan bahan pembersih } \\
\text { yang tepat (jika dibutuhkan). } \\
\text { 6. Pengetahuan dan kemampuan }\end{array}$ \\
\hline
\end{tabular}


Tabel 5 CPOTB proses pra poduksi, produksi dan pasca produksi serta kompetensi yang dibutuhkan pendamping (lanjutan)

\section{Kategori СРОТВ}

No Pengolahan/Pasca Produksi

\section{Prinsip Dasar}

hal ini bertujuan untuk menghindari adanya cemaran.

6. Pengeringan yang tepat dan kadar air yang sesuai untuk simplisia yang akan digunakan.

7. Penyimpanan simplisia yang telah kering atau telah lolos uji mutu atau kualitas dilakukan pada wadah dan kondisi yang sesuai serta diberi label yang menunjukkan status simplisia.

8. Label yang digunakan pada point 7 berbeda dengan label yang digunakan pada poin 2 atau 3, hal ini untuk mempermudah identifikasi dan juga pelabelan hanya dilakukan oleh petugas atau karyawan yang berhak serta bertanggung jawab dalam pengawasan mutu.

9. Penerapan prinsip first in, first out dan first expired, first out dalam penggunaan simplisia dan diatur oleh petugas yang berhak dan bertanggung jawab.

10. Setiap bahan baku yang tidak lolos uji atau tidak memenuhi syarat harus dipisahkan dan ditandai dengan jelas, serta disimpan dengan baik sebelum dilakukan tindakan lanjutan.

2 Pengolahan Pengemasan dan 1. Pengolahan dan pengemasan dilakukan sesuai dengan standar proses yang telah ditetapkan.

2. Verifikasi (dilakukan terhadap standar proses meliputi kecocokan standar, konsistensi standar, pembuktian ulang secara periodik untuk menjamin konsistensi kualitas produk)

3. Pencemaran (analisis standar untuk meminimalisir pencemaran fisik, kimia maupun biologis baik yang sifatnya patogen maupun non patogen yang dapat menurunkan mutu produk)

4. Sistem penomoran kode produksi yang dicatat dalam log book harian yang mencakup tanggal pemberian nomor,

\section{Kompetensi yang Dibutuhkan} Pendamping

first out dan juga first expired, first out.

7. Kemampuan menjelaskan masalah manajemen bahan baku dan pentingnya masalah pengawasan mutu bahan baku.

8. Pengetahuan dan kemampuan manajemen bahan baku yang tidak sesuai (pengolahan, pembuangan limbah atau tindakan lain yang sesuai)

1. Pengetahuan dan kemampuan untuk menganalisa standar proses produksi dan pengolahan bahan baku yang tepat dan sesuai dengan prinsip saintis sehingga tidak menurunkan kualitas dan khasiat atau kandungan khusus dalam bahan baku.

2. Kemampuan menyusun dan menganalisa standar proses pengolahan produk. Pendamping harus memahami jenis dan kategori produk yang dibuat karena CPOTB untuk masingmasing pengolahan produk berbeda, yaitu untuk produk 
Tabel 5 CPOTB proses pra poduksi, produksi dan pasca produksi serta kompetensi yang dibutuhkan pendamping (lanjutan)

\section{Kategori CPOTB}

No Pengolahan/Pasca Produksi
Prinsip Dasar

identitas produk dan besarnya bets yang bersangkutan (bertujuan untuk memudahkan lacak produk dan meningkatkan traceability produk)

5. Penimbangan dan penyerahan (kalibrasi timbangan, pencatatan hasil penimbangan atau perhitungan baik bahan baku, bahan pengemas, produk antara, maupun produk ruahan).

6. Pengolahan (pengecekan kondisi ruangan, peralatan, prosedur pengolahan, bahan, dan hal lainnya yang berkaitan dengan proses pengolahan,air yang digunakan, pakaian dan sanitasi serta higiene karyawan, kondisi sanitasi dan higiene wadah serta penutup bahan, minimalisasi kontaminasi silang, pengawasan proses untuk menjamin mutu produk)

7. Pengemasan (pemastian kebenaran identitas setiap produk ruahan dan ahan pengemas, pengawsan terhadap proses pengemasan dan pemberian identitas terhadap produk jadi, serta pemeriksaan yang teliti dan pengawasan kesesuain produk sebelum dilakukan penyerahan ke bagian karantina atau menunggu proses lanjutan).

8. Penyimpanan (penyimpanan yang terpisah antara produk jadi dengan bahan baku atau bahan lainnya, dan dilakukan dengan prosedur dan kondisi yang sesuai, rapi, penandaan yang jelas, serta penerapan prinsip first in, first out dan first expired, first out).

3 Pengawasan mutu 1 . Pengawasan mutu harus dilakukan dengan sistem dan prosedur yang jelas.

2. Instruksi dan spesifikasi pengawasan mutu tertulis dan jelas baik untuk bahan baku, bahan pengemas, produk antara, produk ruahan, dan juga produk jadi.
Kompetensi yang Dibutuhkan Pendamping

dalam bentuk serbuk, penyarian, cairan, krim, salep, pil, tablet, kapsul atau bentuk padat yang berupa parem, tapel, pilis dan sejenisnya.

3. Pengetahuan tentang pentingnya kalibrasi dan verifikasi standar pengolahan dan peralatan.

4. Pengetahuan dan kemampuan analisa proses pengemasan dan kondisi serta proses penyimpanan yang sesuai untuk bahan baku hingga produk jadi.

5. Pengetahuan dan kemampuan dalam memahami prinsip first in, first out dan juga first expired, first out.

6. Pengetahuan tentang prinsip dan pencegahan cross contamination.

7. Kemampuan menyampaikan prinsip-prinsip di poin 1-6 dalam bahasa yang mudah dipahami oleh produsen dari setiap proses pengolahan dan pengemasan.

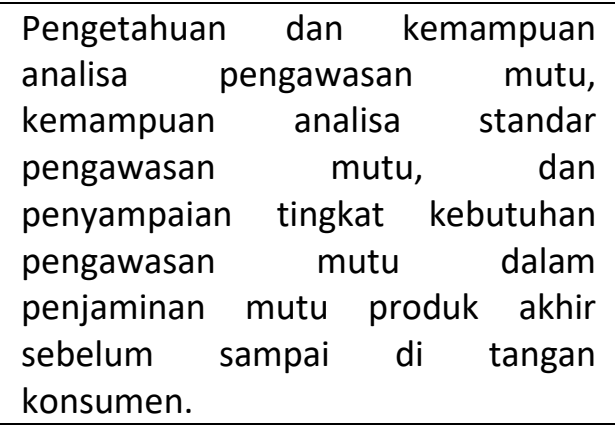




\begin{tabular}{|c|c|c|c|}
\hline No & $\begin{array}{c}\text { Kategori CРОТВ } \\
\text { Pengolahan/Pasca } \\
\text { Produksi }\end{array}$ & Prinsip Dasar & $\begin{array}{c}\text { Kompetensi yang Dibutuhkan } \\
\text { Pendamping }\end{array}$ \\
\hline 4 & Inspeksi Diri & $\begin{array}{l}\text { 1. Bertujuan untuk menilai apakah seluruh } \\
\text { aspek CPOTB telah terpenuhi dari segi } \\
\text { pengolahan, pengemasan hingga } \\
\text { pengendalian mutu. } \\
\text { 2. Yang perlu diinspeksi adalah : personalia, } \\
\text { bangunan termasuk fasilitas untuk } \\
\text { personalia, penyimpanan bahan baku dan } \\
\text { produk jadi, peralatan, pengolahan dan } \\
\text { pengemasan, pengawasan mutu, } \\
\text { dokumentasi, serta pemeliharaan gedung } \\
\text { dan peralatan). }\end{array}$ & $\begin{array}{l}\text { Pengetahuan dan kemampuan untuk } \\
\text { menganalisa proses inspeksi dan } \\
\text { juga mengapa dibutuhkan inspeksi, } \\
\text { termasuk mengapa dibutuhkan } \\
\text { dokumentasi yang jelas dari setiap } \\
\text { proses produksi. }\end{array}$ \\
\hline 5 & Dokumentasi & $\begin{array}{l}\text { Sistem dokumentasi yang dirancang dengan } \\
\text { teliti, mudah diaplikasikan, benar, efektid, dan } \\
\text { manajemen dokumentasi yang baik, } \\
\text { mencakup: } \\
\text { 1. Dokumentasi spesifikasi (bahan baku, } \\
\text { pengemas, produk antara, produk ruahan, } \\
\text { dan produk jadi) } \\
\text { 2. Dokumen produksi induk (standar produk } \\
\text { yang akan dibuat) } \\
\text { 3. Catatan pengolahan bets (mulai dari } \\
\text { penimbangan hingga produk ruahan guna } \\
\text { mempermudah traceability produk) } \\
\text { 4. Catatan pengemasan bets } \\
\text { 5. Dokumen pengawasan mutu } \\
\text { 6. Dokumen penyimpanan dan distribusi } \\
\text { 7. Dokumen pemeliharaan, pembersihan } \\
\text { ruangan dan peralatan } \\
\text { 8. Prosedur dan catatan tentang inspeksi diri } \\
\text { 9. Pedoman tentang pelatihan CPOTB bagi } \\
\text { personalia }\end{array}$ & $\begin{array}{l}\text { Pengetahuan dan kemampuan untuk } \\
\text { menganalisa manajemen dokumen } \\
\text { untuk setiap poin dokumen. }\end{array}$ \\
\hline 6 & $\begin{array}{l}\text { Penanganan } \\
\text { terhadap hasil } \\
\text { pengamatan } \\
\text { produk jadi di } \\
\text { peredaran }\end{array}$ & $\begin{array}{l}\text { Perlunya penanganan terhadap keluhan, } \\
\text { laporan, dan penarikan produk (jika terjadi) } \\
\text { karena hal ini menyangkut masalah hak } \\
\text { konsumen dan kewajiban produsen. }\end{array}$ & $\begin{array}{l}\text { Pengetahuan dan kemampuan } \\
\text { analisa terhadap prosedur recall } \\
\text { atau penarikan produk dan } \\
\text { manajemen keluhan dan keluhan } \\
\text { terhadap produk. }\end{array}$ \\
\hline
\end{tabular}

\section{B. Proses Persiapan Pendaftaran ljin Edar Produk}

Setelah produk yang dihasilkan "bebas masalah" dari berbagai keterbatasan dan siap untuk dijual ke pasaran, hal yang paling penting dan tidak boleh dilupakan adalah pengajuan ijin edar produk.
Berikut adalah kompetensi yang wajib dimiliki oleh pendamping terkait dengan masalah ijin edar produk: 


\section{Memahami kategori produk serta aturan yang terkait ijin edar produk}

Pendamping harus memahami produk yang akan diajukan untuk ijin edar ini masuk kategori produk apa, apakah cukup dengan ijin edar dari Dinas Kesehatan berupa P-IRT atau harus ijin edar BPOM. Misal jika produk tersebut memiliki ketahanan lebih dari 7 hari, maka ijin edar dapat dilakukan ke Dinkes atau P-IRT saja, namun jika produk tersebut masuk dalam kategori produk yang harus ijin BPOM, maka harus didaftarkan ke BPOM (BPOM 2016a). Pendaftaran obat tradisional tersebut masuk kategori berapa, dan bagaimana mekanisme pendaftaran kategori produk tersebut, melalui jalur berapakah produk harus didaftarkan, dan hal lain yang berkaitan.

Misalnya untuk produk jamu dengan klaim kesehatan tentu ijinnya harus ke BPOM. Bagaimana analisa untuk pembuktian klaim kesehatan dan kalim manfaat produk juga harus dipahami oleh pendamping. Contoh jamu serbuk asam urat, produk tersebut harus melalui ijin edar BPOM karena merupakan produk dengan klaim kesehatan "mengobati asam urat", meskipun jika dilihat dari bentuknya berupa serbuk kering yang tahan selama lebih dari tujuh hari, namun klaim kesehatan yang ikut serta dalam kemasan produk akan merujuk pada ijin edar BPOM.

Contoh lain untuk masalah kategori produk, jika produk tersebut adalah berupa serbuk asam urat, yang mengandung simplisia berasal dari Indonesia (indigenous) maka termasuk kategori 1 pada saat pendaftaran. Untuk jalur pendaftaran, misal produk tersebut juga menggunakan nama dagang selain nama umumnya, maka produk akan melalui jalur 2, dengan lama proses registrasi selama 15 hari kerja setelah diterimanya berkas pendaftaran dan bukti pembayaran.

Selain itu, untuk aturan ijin edar, pendamping juga harus memahami tentang Peraturan Menteri Kesehatan Republik Indonesia Nomor 007 Tahun 2012 tentang Registrasi obat Tradisional dan Peraturan Kepala Badan Pengawas Obat dan Makanan Republik Indonesia Nomor HK.00.05.41.1384

\section{Memahami tatacara pengajuan ijin edar}

Setiap pendamping harus memiliki pengetahuan dan pemahaman yang cukup baik untuk proses dan tatacara pengajuan ijin edar. Hal ini untuk mempermudah pihak yang didampingi agar proses pengajuan ijin edar dapat berjalan lancar, termasuk persiapan dokumen baik dokumen administrasi maupun dokumen pendukung agar lebih matang. Pendamping harus memahami bagaimana tahap pendaftarannya, baik tahap pra-penilaian ataupun tahap penilaian hingga penggunaan ijin edar, terkait juga larangan dan sanksinya. Pendamping harus mengarahkan bagaimana menglengkapi berkas dari mulai data perusahan, data pabrik, upload data, permohonan dan pengiriman berkas, hingga ikut memonitoring verifikasi, pembayaran dan juga validasi dan penerbitan SPP, dan seterusnya.

\section{Proses sosial dalam melakukan pendampingan terhadap para pelaku usaha industri jamu}

Pendamping harus memiliki kemampuan dalam menjelaskan masalah teknis yang mungkin kurang atau sulit dipahami oleh produsen, karena terkadang ada hal-hal yang sulit untuk dijelaskan secara saintis dan membutuhkan kemampuan untuk "menyederhakan" istilah atau aturan menjadi Bahasa yang mudah dipahami.

Misalnya, peraturan dari CPOTB mensyaratkan bahwa bangunan yang sesuai adalah bangunan dengan pertemuan dinding dan lantai yang lengkung dan tidak membentuk sudut, maka kita harus menjelaskan bahwa tujuan dari konstruksi yang demikian adalah agar bangunan lebih mudah dibersihkan dan meminimalisir kontaminasi.

Contoh lain adalah masalah mengapa harus ada log book setiap produksi dan penulisan kode produksi, bagaimana aturan penulisannya, mengapa harus ada kode produksi. Maka kita harus menjelaskan fungsi dari kode produksi sebagai "pelacak" dari setiap produk yang keluar dari pabrik, supaya jika ada masalah pada satu produk, maka kita bisa melihat rekam produk tersebut dari mulai bahan baku masuk hingga keluar dari tempat produksi. Kita dapat melihat keseluruhannya dalam log book yang telah dibuat.

\section{KESIMPULAN}

\section{Kesimpulan}

Pendampingan dalam proses pengajuan ijin edar produk jamu sangat dibutuhkan oleh pelaku usaha jamu di Kecamatan Nguter, Kabupaten Sukoharjo. Pendamping yang dibutuhkan bukan hanya pendamping yang membantu mengarahkan pengurusan ijin edarnya saja, namun juga memiliki kompetensi dalam hal-hal teknis yang berkaitan dengan CPOTB dan SNI karena pelaku usaha jamu memiliki begitu banyak permasalahan dan kekurangan

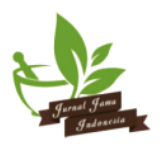


tenaga ahli untuk menyelesaikan masalah-masalah dan menghasilkan produk yang memenuhi standar. Kompetensi yang harus dipenuhi oleh pendamping dalam hal ini adalah untuk membantu pelaku usaha dalam menyiapkan produknya hingga produk memenuhi standar yang dipersyaratkan, hingga pengajuan atau pendaftaran ijin edar dan aplikasi ijin edar, termasuk bagaimana langkah bijak dalam penggunaan ijin edar yang telah dimiliki nantinya.

\section{Saran}

Dinas Perdagangan dan Perindustrian sebaiknya mulai memperhatikan kebutuhan pendampingan bagi para pelaku usaha jamu. Hal ini karena produk jamu sendiri merupakan produk yang sangat berpotensi untuk dikembangkan dalam pasar persaingan global sebagai produk indigenous atau asli Indonesia yang dikembangkan secara turun temurun dan merupakan salah satu aset budaya juga. Selain itu, pelaku usaha tidak hanya membutuhkan dana sebagai unsur bantuan, namun juga pendamping atau konsultan untuk memecahkan masalah yang dihadapi guna menghasilkan produk yang memenuhi standar dan dapat bersaing secara global. Dalam implementasinya, Disperindag dapat menjalin kerja sama dengan dinas lain, misalnya Dinas kesehatan untuk membantu sosialisasi dan konsultasi masalah limbah, sanitasi dan higiene karena setiap komponen yang ada dalam СРОTB harus terpenuhi. Sehingga jika Disperindag tidak mampu mengatasi semua permasalahan, kerja sama dengan dinas lain merupakan solusi yang paling tepat.

\section{DAFTAR PUSTAKA}

Arafa H. 2005. Curcumin attenuates diet-induced hypercholesterolemia in rats. Medical Science Monitor. 11(7):228-234.

Devy L. 2009. Analysis of variance and genetic stability of temulawak (Curcuma xanthorrhiza Roxb.) in Indonesia. [tesis]. Bogor (ID): Sekolah Pascasarjana, Institut Pertanian Bogor.

Farombi E, Shrotriya S, Na H, Kim D, Surh Y. 2007. Curcumin attenuates dimethylnitrosamineinduced liver injury in rats through Nrf2mediated induction of heme oxygenase-1. Food and Chemical Toxicology. 46(4):1279-1287.

Figueiredo AC, Barroso JG, Pedro LG, \& Scheffer JJ. 2008. Factors affecting secondary metabolite production in plants: volatile components and essential oils. Flavour and Fragrance Journal. 23:213-226.

Goel A, Kunnumakkara A, Aggarwal B. 2008. Curcumin as "Curecumin": from kitchen to clinic. Biochemical Pharmacology. 75(4):787-809.

Herlina. 2011. Kajian variasi jarak dan waktu tanam jagung manis dalam sistem tumpang sari jagung manis (Zea mays). Padang (ID): Universitas Andalas.

Indriati TR. 2009. Pengaruh Dosis Pupuk Organik dan Populasi Tanaman terhadap Pertumbuhan serta Hasil Tumpang sari Kedelai (Glycine max L.) dan Jagung (Zea mays L.). [tesis]. Surakarta (ID): Program Pascasarjana, Universitas Sebelas Maret.

Islam F, Karim MR, Shahjahan M, Hoque MO, Alam MR, \& Hossain MA. 2002. Study on the effect of plant spacing on the production of turmeric at farmer's field. Asian Journal of Plant Sciences. 1(6): 616617.

Jacob A, Wu R, Zhou M, Wang P. 2007. Mechanism of the Anti-inflammatory Effect of Curcumin: PPARgamma Activation. PPAR Research 2007, 89369.

Kumar P, Padi S, Naidu P, Kumar A. 2007. Possible neuroprotective mechanisms of curcumin in attenuating 3-nitropropionic acid-induced neurotoxicity. Methods and Findings in Experimental and Clinical Pharmacology. 29(1):19-25.

Nurcholis W, Ambarsari L, Purwakusumah ED. 2016. Curcumin analysis and cytotoxic activities of some Curcuma xanthorrhiza Roxb. Accessions. International Journal of PharmTech Research. 9(7):175-180.

Rahardjo M. 2010. Penerapan SOP budi daya untuk mendukung temulawak sebagai bahan baku obat potensial. Perspektif. 9(2):78-93.

Razaq M, Zhang P, Shen H, Salahuddin. 2017. Influence of nitrogen and phosporus on the growth and root morphology of Acer Mono. PLOS ONE. 12(2):e0171321

Sidik, Sumiwi SA. 2009. Temulawak (Curcuma xanthorrhiza Roxb.) Botany, Etnobotany Chemistry, Pharmacology and There Benefit. Proceedings of The First International Symposium on Temulawak. 27-28 May 2008. Bogor (ID): Biopharmaca Research Center Bogor Agricultural University . 
Song YN, Zhang FS, Marschner P, Fan FL, Gao HM, Bao $X G$, Li L. 2007. Effect of intercropping on crop yield and chemical and microbiological properties in rizhosfer of wheat (Triticum aestivum L.), maize (Zea mays L.), and faba bean (Vicia faba L.). Biology and Fertility of Soils. 43(5):565-574.
Thangapazham R, Puri A, Tele S, Blumenthal R, Maheshwari R. 2008. Evaluation of a nanotechnology-based carrier for delivery of curcumin in prostate cancer cells. International Journal of Oncology. 32(5):1119-1123.

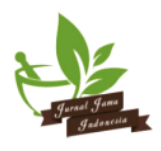

